Resumo: Um método "spot-test" qualitativo e seqüencialmente quantitativo é proposto para análise de dipirona em fármaco "puro" e em preparações farmacêuticas. A formação de coloração vermelho-violeta indica um resultado qualitativo positivo. Na seqüência, um procedimento quantitativo pode ser realizado no mesmo frasco. Os resultados quantitativos obtidos foram comparados estatisticamente com os resultados obtidos pelo método indicado pela Farmacopéia Brasileira, utilizando o teste $\boldsymbol{t}$ de Student e o teste $\boldsymbol{F}$. Considerando a concentração em uma alíquota de $100 \mu \mathrm{L}$, o limite qualitativo visual de detecção foi de cerca $5 \times 10^{-6} \mathrm{~g}$. instrude $\mathrm{LOQ} \cong 4.5 \times 10^{-4} \mathrm{~mol} \mathrm{~L}^{-1}$

Palavras-chave: dipirona, spot-test, análise, qualitativa, quantitativa

\section{References}

[1] Brazilian Pharmacopoeia, 3rd ed., Organização Andrei Editora, São Paulo, Brazil, 1977, p 406-8.

[2] 1.M. Benseñor, São Paulo Med. J., 119 (2001) 190

[3] H. Ergün, D. A. C. Frattarelli and J. Aranda, J. Pharma-

[4] P. Danielli, and M.B Leal, Rev. Bras. Farm., 84 (2003)

[5] Y. Bentur, and O. Cohen, J. Toxicol.-Clin. Toxic., 42 (2004) 261

[6] S. C. Pierre, R. Schmidt, C. Brenneis, M. Michaelis, G. Geisslinger, and

[7] G. Suarez-Kurtz , F.M. Ribeiro, R.C.E. Estrela, F.L. Vicente, and C J. Struchiner, Braz. J. Med. Biol. Res., 34 (2001) 1475 .

[8] Brasil, Anvisa, Agência Nacional de Vigilância Sanitária, Rev. Saúde Pública, 38 (2004) 748.

[9] F.G.D. Vieira, J. M. Crubellate, I.G. Silva, and W.R. Silva, RAE eletron., 1 (2002) 1

[10] H. Senyuva, I. Aksahin, S. Ozcan, and B.V. Kabasakal, Anal. Chim. Acta, 547 (2005)73-7.

[11] K.A. Sakiara, L. Pezza, C. B. Melios, H. R. Pezza, and M. Moraes, Farmaco, 54 (1999) 629.

[12] J. L. F. C. Lima, S. M. O. Sá, J. L. Santos, and E. A. G, Zagatto, J. Pharmaceut. Biomed., 32 (2003)1011.

[13] L. H. Marcolino Jr, R. A. Souza, O. Fatibello Filho, and F.C. Moraes, Anal. Lett., 38 (2005) 2315 .

[14] A.V. Pereira, L. Penckowski, M. Vosgerau, and M. F. Sassá, Quím. Nova 25 (2002)553.

[15] A. P. Nascimento, M. G. Trevisan, E. R. M. Kedor-Hackmann, and R. J. Poppi, Anal. Lett., 40 (2007) 975.

[16] J. S. Albuquerque, V. L. Silva, F. Lima, A. Araújo, and M. C. B. S. M.Montenegro, Anal. Sci., 19 (2003) 692

[17] T. R. L. C. Paixão, C. R. Matos, and M. Bertotti, Talanta, $61(2003) 725$.

\title{
PRODUCTION OF BIODIESEL FROM BABASSU OIL USING METHANOL-ETHANOL BLENDS
}

F. C. Silva $A^{*}$, K. S. B. Cavalcante ${ }^{A, B}$, H. C. Louzeiro ${ }^{A, B}$, K. R. M. Moura ${ }^{A}$, A. P. Maciel ${ }^{A}$, L. E. B. Soledade ${ }^{B}$, A. G. Souza ${ }^{B}$

SOF 040, São Luis, MA, Brazil.

18] E. P. Medeiros, S.L. Castro, F. M. Formiga, S. R. B. San-

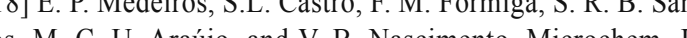
$78(2004) 91$.

[19] L. H. Marcolino Jr, V. G. Bonifácio, and O. Fatibello Filho, Quím. Nova, 28 (2005) 783.

20] M. F. S Teixeira, L. H. Marcolino Jr., O. Fatibello Filho, E. R. Dockal, and E. T. G. Cavalheiro, J. Braz. Chem. Soc, 15 (2004) 803 .

[21] P. L.Weinert, L. Pezza, and H.R. Pezza, J. Braz. Chem. Soc., 18 (2007) 846

[22] F. Feigl, Spot Tests in Organic Analysis, 7th ed., Elsevier, Amsterdan, 1966, p. 434-36 and 635.

23] L. Pezza, M. Tubino, C. B. Melios, and H. R. Pezza, Anal. Sci., 16 (2000) 313.

[24] K. Eckschlager, Errors, Measurement and Results in Chemical Analysis, Van Nostrand Reinhold Company, London, 1972, p. 109-120.

[25] P. Karrer, Organic Chemistry, 4th ed.; Wiley, New York, 1950, p. 798

[26] P. E. Georghiou, and C.K. Ho, Can. J. Chem., 67 (1989) 871

\section{Introduction}

Babassu nut is the main product of the vegetal extractive activities in Maranhão state, Brazil and one quarter of its territory is covered by such native palm tree (Orbignya phalerata). The activities related to the babassu nut generate about 300 thousand jobs, from the collect normally made by

Maranhão is the biggest producer of babassu nuts in Brazil. It is responsible for the production of almost $80 \%$ of the county ouput, corresponding to 120 housand me 2005 base year 130 . Thousand metric tons in the 2005 base year. [3]. The local industries produce about 60 thousand metric tons /year of babassu oil, being most of it transported to other Brazilian states [4]
Babassu oil displays a high percentage of saturated fatty acids, $91 \%$, mainly composed of lauric acid (48\%), myristic acid (16\%), palmitic acid $(10 \%)$, stearic acid $(2 \%)$ and others $(5 \%)$. It also presents $19 \%$ of unsaturated fatty acids, chiefly oleic (14\%) and linoleic (5\%) acids [5].

Maranhão is also the second biggest soybean producer in Northeastern Brazil, only behind Bahia state. In the 2006/2007 harvest, according to CONAB, the soybean production in Maranhão was of about 0.967 million metric tons, while million me tons, while million metric tons [6]. metric tons [6]

Besides these two cultures, Maranhão displays a big potential for the cultivation of other oleaginous species (castor oil plant, cotton, tame nut, etc.), due to its weather conditions, geogra- 
phic location and agricultural tradition. A big part number 42 of the Brazilian National Petroleum of such production can be transformed in the biodiesel fuel.

Biodiesel is defined as a fuel composed of alkyl esters of long chain fatty acids, derived from vegetable oils or animal fats $[7,8]$. This fuel can be used in any diesel cycle engine, without the need of adaptations.

Owed to technical and economic reasons, the industries use more often methanol $(\mathrm{MeOH})$ in the biodiesel production process. However, this alcohol presents several drawbacks, such as its high toxicity, being synthesized from non renewable sources, besides the fact that Brazil is not auto-sufficient in its production [9].

Although ethanol has a higher cost per ton, the biodiesel production by means of the ethanol route is attractive under the strategic standpoint, as Brazil is the biggest ethanol producer in the world. As for the environmental aspects, ethanol is not toxic and since it is produced from renewable sources, the whole biodiesel is $100 \%$ renewable $[10,11]$

One of the ways of combining the technical and economic advantages of methanol with the environmental advantages of ethanol is to obtin biodiesel from a biodicse from a ben of these alcohols. Therefoof the transesterification process of degummed, of the transesterification process of degummed,
neutralized and clarified babassu oil, using blends neutralized and clarified babassu oil, using blends
of different proportions of these alcohols with homogeneous catalysis [12].

\section{Experimenta}

The reagents utilized were: commercial clarified babassu oil (OLEAMA), anhydrous ethanol (Petrobrás Distribuidora), methanol P.A. (Quimis) and potassium hydroxide $85 \%$ (Quimis) as catalyst. The raw materials were analyzed following the Standard Methods for the Analysis of Oils, Fats and Derivatives (SMAOFD). For the characterization of the methyl/ethyl biodiesel from babassu were utilized the standards from sel from babassu were utilized the standards from
the Brazilian Association of Technical Standards the Brazilian Association of Technical Standards
(ABNT) and the American Society for Testing and (ABNT) and the American Society for Testing and
Materials (ASTM), indicated in the Resolution
Agency (ANP) [7].

In the experiments, were utilized a $\mathrm{pHme}-$ er Quimis model Q400M2, a mechanical stitre and a gas chromatograph VARIAN CP 3800.

The procedure for the transesterification reaction starts by dissolving $\mathrm{KOH}$ in the methanol/ thanol blend, under stirring at room temperature. Next, add to this solution $100 \mathrm{~g}$ of oil under stirring Remove the alcohol excess by distillation under reduced pressure. Transfer the mixture of esters and glycerin to a separatory funnel and allow settling for 12 hours. Afterwards, separate and weigh both phases and wash the biodiesel, using the air (n) air 0.1 wash 1 Ming with water until reaching the pH 7.0. Dry the biodiesel in an oven at $100^{\circ} \mathrm{C}$ for 3 hours, allow cooling an weigh, for further physico-chemical tests.

\section{Results and discussion}

The best reaction conditions to obtain methyl and ethyl babassu biodiesel were determined by Silva and Brandão: oil/methanol molar ratio of 1:4.6, $\mathrm{KOH}$ content of $1.5 \%, 30$ min of reaction time, stirring of $1760 \mathrm{rpm}$ and room temperature [13]. Using the methanol mass as reference, several MeOH:EtOH ratios were investigated, aiming the optimization of the babassu oil trasting at the optimizas ro the babassu oil transesteriication process. Table 1 presents the percentage and volumes of the alcohols used in the babassu oil transesterification reactions. and allow the reaction up to the phase separation.
Table 1. Methanol/ethanol proportions used for obtaining methyl/ethyl babassu biodiesel

\begin{tabular}{cccccc}
\hline \multicolumn{3}{c}{ METHANOL } & \multicolumn{3}{c}{ ETHANOL } \\
\hline$\%(\mathrm{v} / \mathrm{v})$ & $\mathrm{m}(\mathrm{g})$ & $\mathrm{V}(\mathrm{mL})$ & $\%(\mathrm{v} / \mathrm{v})$ & $\mathrm{m}(\mathrm{g})$ & $\mathrm{V}(\mathrm{mL})$ \\
$100 \%$ & 21.33 & 27.0 & $0 \%$ & 0 & 0 \\
\hline $90 \%$ & 19.20 & 24.3 & $10 \%$ & 2.13 & 2.7 \\
$80 \%$ & 17.06 & 21.6 & $20 \%$ & 4.26 & 5.4 \\
\hline $70 \%$ & 14.93 & 18.9 & $30 \%$ & 6.39 & 8.1 \\
$60 \%$ & 12.79 & 16.2 & $40 \%$ & 8.53 & 10.8 \\
\hline $50 \%$ & 10.66 & 13.5 & $50 \%$ & 11.66 & 13.5 \\
\hline
\end{tabular}

In order to determine the best methanol/ethanol ratio, the process of spontaneous biodiesel/ glycerin separation was analyzed. The produced biodiesel is composed of methyl and ethyl esters of the fatty acids that make up the babassu oil. In the chromatogram of Figure 1, it can be observed that there are two peaks derived from the same fatty acid. This occurs because one peak is obtained from the fatty acid reacting with methanol and the other peak reacting with ethanol. As they display different retention times, it is possible to detect them separately.

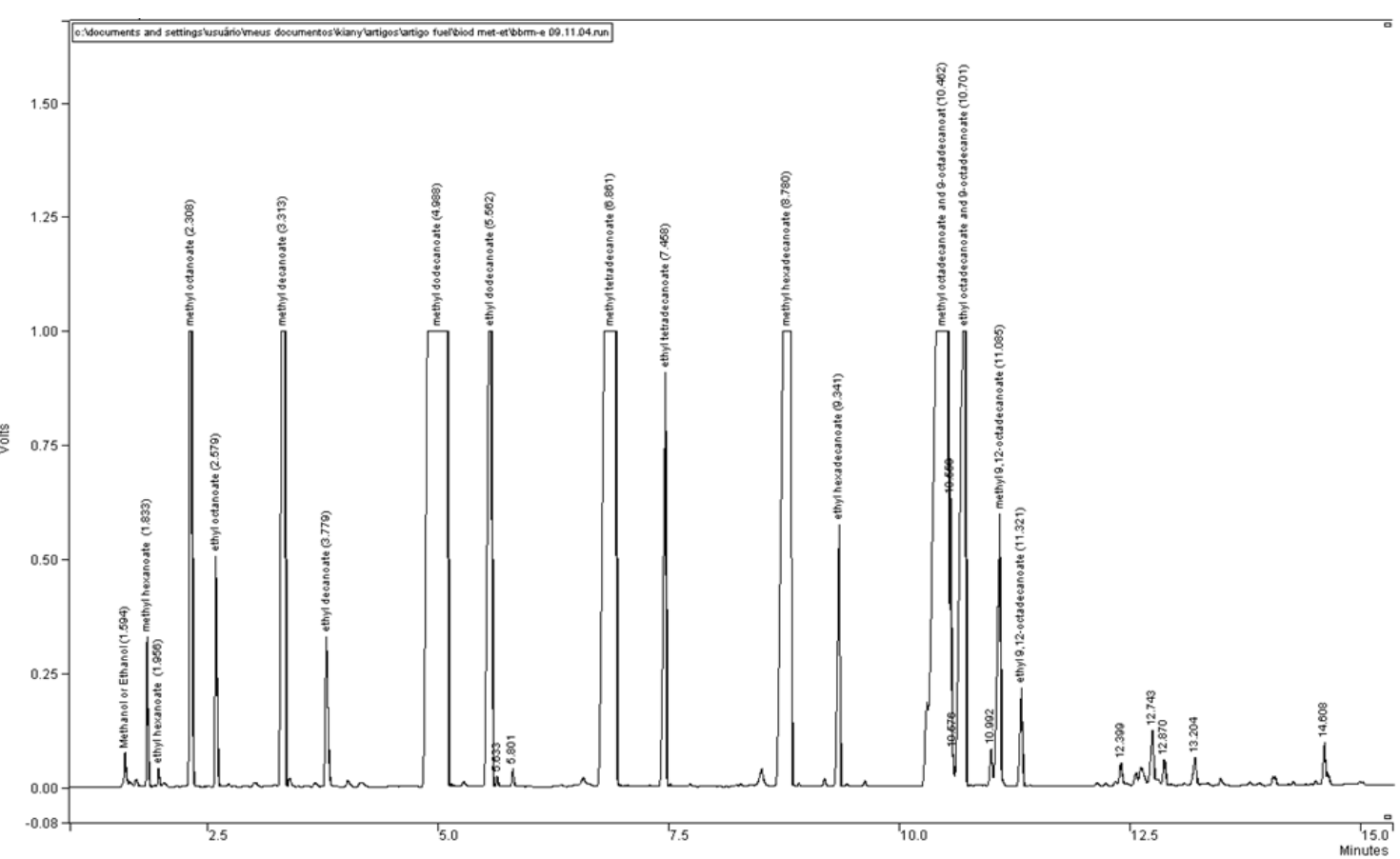

Figure 1. Chromatogram of the babassu methyl/ethyl biodiesel

The ester percentages (E), determined by gas chromatography, are obtained from the sum of all methyl and ethyl esters. The ester percentages and the yield, reported in relation to the mass of pure methyl/ethyl biodiesel (BP), both for the several $\mathrm{MeOH} / \mathrm{EtOH}$ ratios, are listed in Table 2. 
Table 2. Influence of the ethanol/methanol ratio on the yield and ester percentages of babassu biodiese

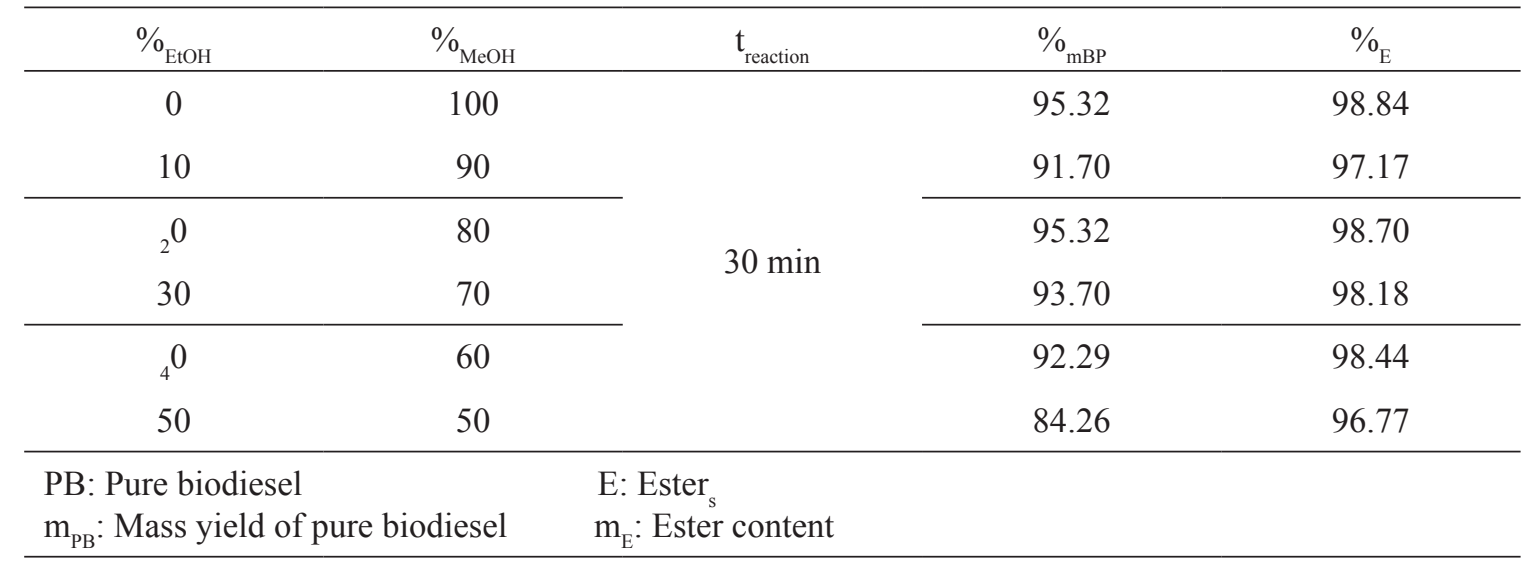

The separation of the biodiesel/glycerin mixture does not occur spontaneously using ethanol percentages higher than $50 \%$, even with the removal of the alcohol excess by means of distillation under
reduced pressure. It was observed that the mass yield of pure biodiesel tends to diminish with the increreduced pressure. It was observed that the mass yield of pure biodiesel tends to diminish with the incre-
ase of the ethanol proportion in the blend, due to the difficulty of the biodiesel/glycerin separation.

In Figure 2 shows the influence of the ethanol percentage of the methanol/ethanol blends on the ester content and the mass yield of pure biodiesel, for a fixed reaction time of $30 \mathrm{~min}$

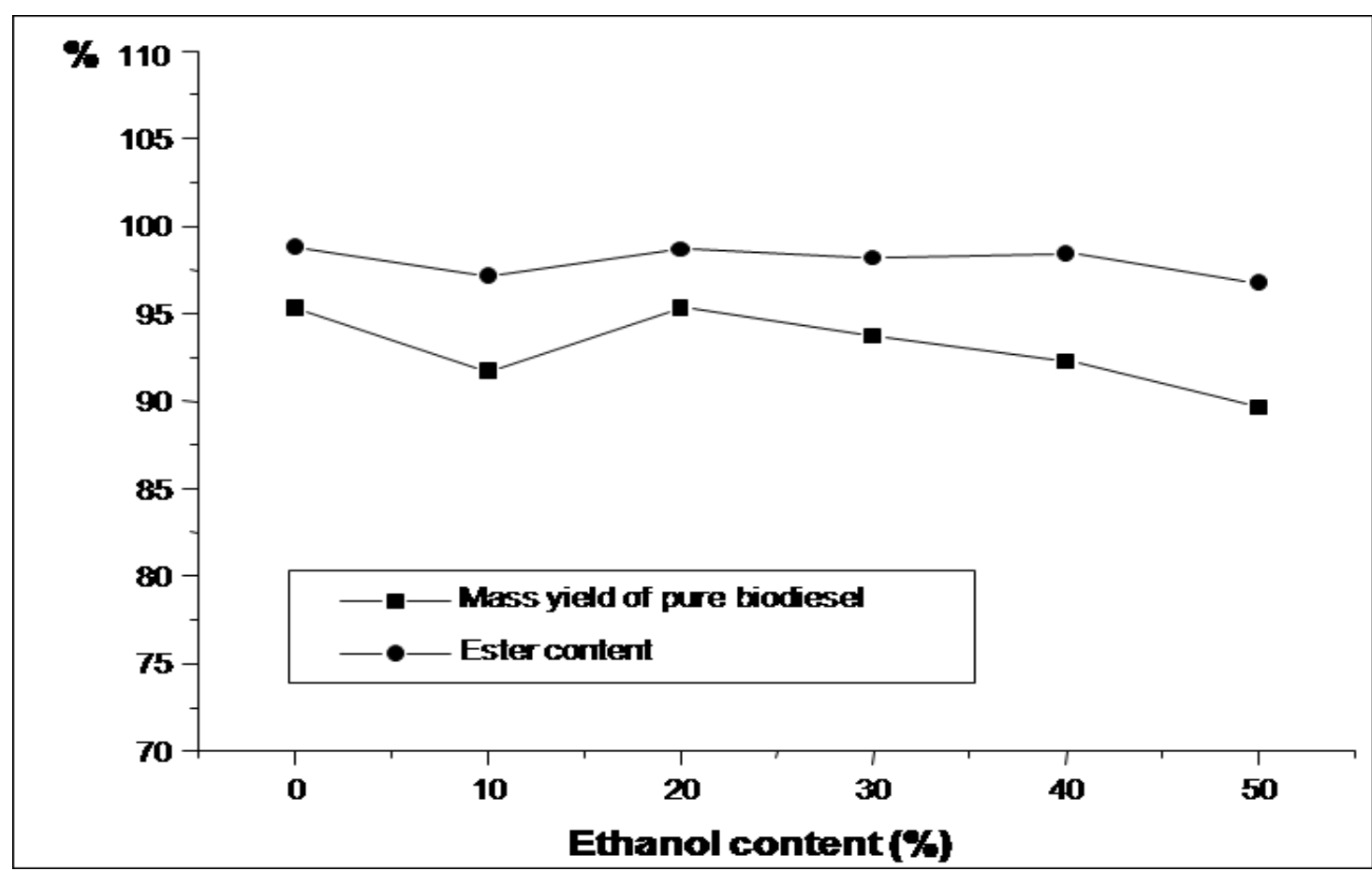

Figure 2. Influence of the $\mathrm{MeOH}: \mathrm{EtOH}$ ratio on the ester content and on the mass yield of pure biodiesel, for a reaction time of $30 \mathrm{~min}$
The results point out that, for a fixed reaction time of $30 \mathrm{~min}$, there was no meaningful change in the amount of methyl/ethyl esters with the increase of the ethanol percentage. All the samples presented ester contents in the average of $98 \%$, values above the requirements of the ANP [7], with the exception of the biodiesel obtained with a MeOH:EtOH 50:50 ratio. The mass yield of pure biodiesel obtained do not decrease with the ethanol percentage up to $20 \%(\mathrm{v} / \mathrm{v})$ ethanol. However, for higher ethanol concentrations, it is shown a tendency of decreasing the mass yield with further ethanol enrichment in the blend. The value for pure methyl ester $(95.32 \%)$ is higher than the value reported by Oliveira et al. (91\%), also for lso for [5] These results point out an opti-

Table 3. Babassu oil transesterification reactions with $50 \%$ ethanol using different reaction times

\begin{tabular}{ccccc}
\hline$\%_{\text {EtOH }}$ & $\%_{\text {MeOH }}$ & $\mathrm{T}_{\text {reaction }}(\min )$ & $\%_{\mathrm{PB}}$ & $\%_{\mathrm{E}}$ \\
\hline \multirow{2}{*}{50} & \multirow{2}{*}{50} & 30 & 84.26 & 96.77 \\
& & 60 & 83.22 & 98.13 \\
& 90 & 84.52 & 99.03 \\
\hline
\end{tabular}

Figure 3 shows that the ester content increases with the reaction time. It was experimentally verified that the biodiesel/glycerin phase separation and the biodiesel washing processes were more efficient, but the mass yield of pure biodiesel did not increase significantly with the increase of the reaction time. It was shown that all the samples obtained with 50\% ethanol meet the minimum ester content established in the ANP. 


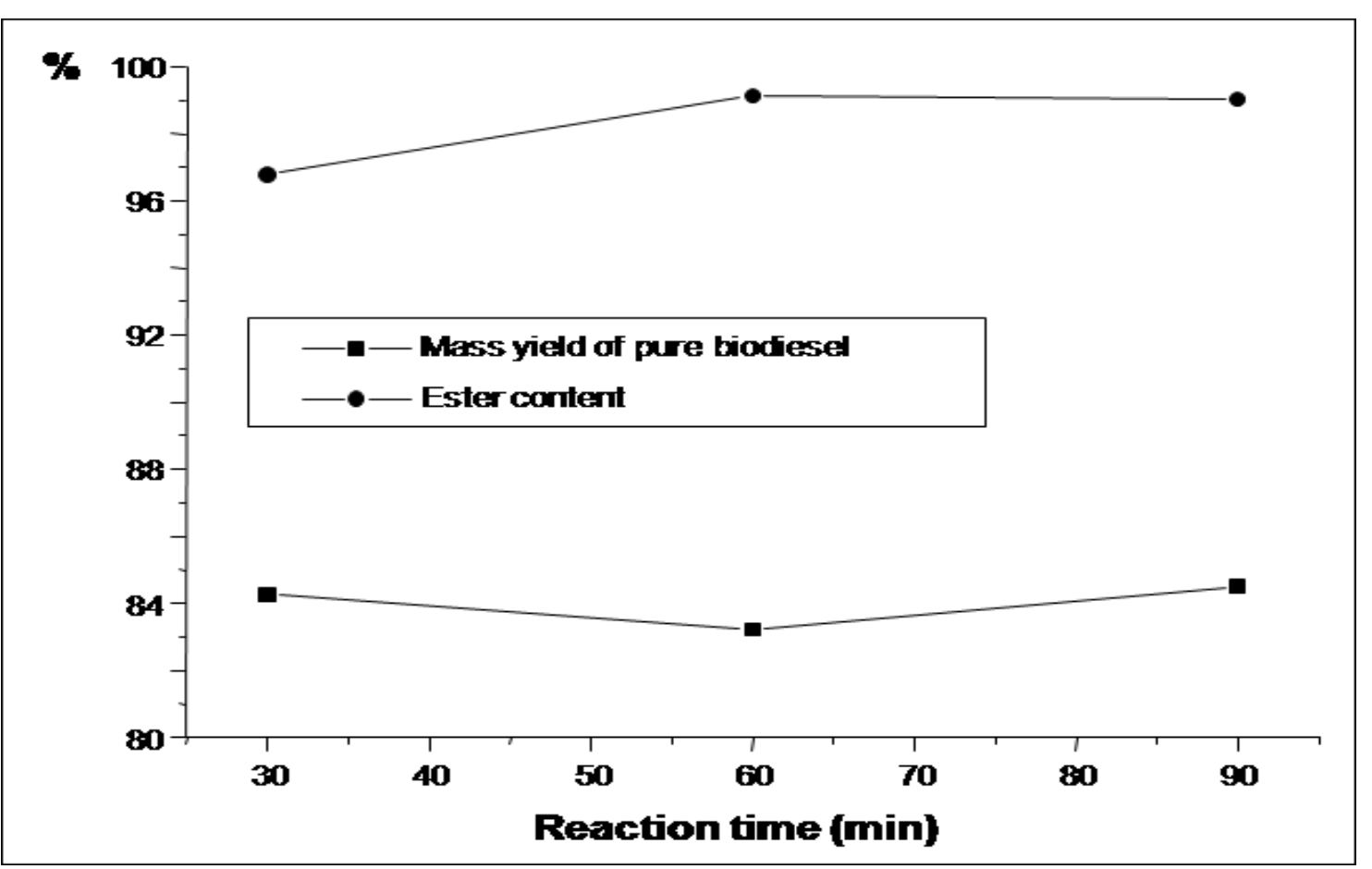

Figure 3. Influence of the reaction time on the mass yield of pure biodiesel and the ester content.

As for the physico-chemical properties, the time is of 60 minutes, in order to obtain satisfacbabassu oil was analyzed utilizing SMAOFD [14] tory ester contents $(98.13 \%)$. The samples of biomethods and the methyl/ethyl biodiesel analyses diesel produced with the $80 \% \mathrm{MeOH}: 20 \% \mathrm{EtOH}$ employed ASTM and ABNT standards. Table 4 blend meet the specifications required by ANP shows the results of some physico-chemical tests taking into account the physico-chemical tests lisof the biodiesel sample obtained with the 80:20 ted in Table 4 methanol/ethanol blend, as well as the specification limits of the standards.

\section{Conclusions}

The following reaction conditions were shown to optimize the biodiesel production from the transesterification of babassu oil with a blend of alcohols: meth of alch: $30 \%$ : : $20 \%$ EtOH me 30 mines of these conditions, a biodiesel mass yield equal or higher than $95.32 \%$ was obtained and also an ester content of $98.70 \%$ was achieved, thus meeting the specification of the ANP. It was also observed that it is possible to utilize an ethanol/methanol mass ratio of 50:50, provided that the reaction

Table 4. Physico-chemical analyses of babassu oil and the biodiesel obtained from a 80:20 methanol/ethanol blend

\begin{tabular}{ccccc}
\hline Tests & Babassu oil & Methyl/ethyl biodiesel & Biodiesel Analysis Method & Biodiesel Limits \\
\hline Moisture and sediments $(\% \mathrm{v} / \mathrm{v})$ & 0.039 & 0.028 & ASTM D-2709 & 0.050 \\
\hline Specific gravity at $25^{\circ} \mathrm{C}\left(\mathrm{kg} / \mathrm{m}^{3}\right)$ & 923.0 & 887.2 & ASTM D-4052* & $860-900$ \\
\hline Kinematic viscosity at $40^{\circ} \mathrm{C}\left(\mathrm{mm}^{2} / \mathrm{s}\right)$ & 34.840 & 4.830 & ASTM D-445* & - \\
\hline Methanol $/$ Ethanol $(\% \mathrm{~m} / \mathrm{m})$ & - & 0.453 & ABNT NBR 15343** & 0.5 (max.) \\
\hline Free glycerin $(\% \mathrm{~m} / \mathrm{m})$ & - & 0.026 & ASTM D-6584* & 0.02 (max.) \\
\hline Esters $(\% \mathrm{~m} / \mathrm{m})$ & - & $>96.500$ & ABNT NBR 15342** & 96.5 (min.) \\
\hline * Standards from ASTM - American Society for Testing and Materials & & \\
** Standards from ABNT - Brazilian Association for Technical Norms & & \\
\hline
\end{tabular}

\section{Acnowledgements}

The authors acknowledge CAPES and CNPq for the scholarships and FAPEMA, ELETRONOR$\mathrm{TE}$ and BNB for the financial support.

Resumo: O Estado de Maranhão no Brasil apresenta um potencial grande para o cultivo de várias espécies oleaginosas, como babaçu, feijão-soja, planta de óleo de rícino, etc... Estes óleo vegetais podem ser transformados em biodiesel pela reação de transesterificacão em meio alcalino, usando metanol ou etanol. A produção de biodiesel a partir da mistura destes álcoois é uma forma de acrescentar as vantagens técnicas e econômicas do metanol às vantagens ambientais do etanol. A mistura de álcool otimizada foi observada usando a relação de volume bientais do etanol. A mistura de álcool otimizada foi observada usando a relação de volume
metanol/etanol de $80 \% \mathrm{MeOH}: 20 \%$ EtOH. O teor de ésteres foi de $98.70 \%$, um valor acima metanol/etanol de $80 \% \mathrm{MeOH}: 20 \%$ EtOH. O teor de ésteres foi de $98.70 \%$, um valor acima Este biodiesel cumpre as especificações de umidade, massa específica, viscosidade cinemática e percentagens de álcoois livres (metanol mais etanol) e glicerina livre.

Palavras chaves: Óleo de babaçu, metanol, etanol, ésteres metílicos, ésteres de etílicos.

\section{References}

[1] Zilbersztajn D. Reorganization of the babassu farm business in Maranhão state, Brazil. 1st ed. São Paulo: USP, 2000. [2] Pinheiro CUB, Frazão JMF. Integral processing of ba-

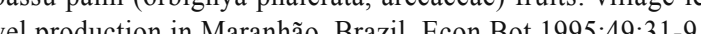
[3] IBGE - Brazilin National Institute of Georaphy and Statistics. Production of vegetable extroction and forestry. Brália: PBGE Prs 2004 .

Bute of producing in[5] Oliveira IS, Montalvã R, Daher L, Surez PAZ, R bim JC. Determination of methyl ester contents in biodiesel blends by FTIR-ATR and FTNIR spectrocopies. Talnta $2006 \cdot 69 \cdot 1278-84$
[6] CONAB - Brazilian National Supply Company, Brazilian Ministry of Agriculture, Cattle Raising and Supply. Available at: http://www.conab.gov.br. Accessed at March 12, 2007.

[7] ANP - Brazilian National Agency for Petroleum, Natura Gas and Biofuels. Resolution number 7, of March 19, 2008 . Brasília, DF, Brazil: Diário Oficial da União

[8] Fangrui M, Clements LD, Milford AH. Biodiesel fuel from animal fat. Ancillary studies on transesterification of beef tallow, Ind Eng Chem Res 1998;37:3768-71.

[9] Costa Neto PR, Rossi LFS, Zagonel GF, Ramos LP. The utilization of used frying oil for the production of biodiesel. Quim. Nova 2000;23:531-7.

[10] Schuchardt U, Sercheli R, Vargas RM. Transesterification of vegetable oils: a review. J Braz Chem Soc 1998;9:199210.

[11] Bergamini MF, Vital SI, Santos AL, Stradiotto NR. Lead ions determination in ethanol fuel by differential pulse an- 


\section{SENSITIVE SPECTROPHOTOMETRIC \\ DETERMINATION OF LAMOTRIGINE IN BULK DRUG AND PHARMACEUTICAL FORMULATIONS USING BROMOCRESOL GREEN}

N. Rajendraprasad, K. Basavaiah* ${ }^{*}$ and K. B. Vinay

\author{
Department of Chemistry, University of Mysore, Manasagangothri, Mysore-570 006, India
}

"Corresponding e-mail: basavaiahk@yahoo.co.in. Mobile: +91-9448939105
Fax: 0091-821-2421263, 2516133.

\begin{abstract}
Two new, simple, rapid and reproducible spectrophotometric methods have been de-
veloped for the determination of lamotrigine (LMT) both in pure form and in its tablets. The first method (method A) is based on the formation of a colored ion-pair complex $(1: 1 \mathrm{drug} /$ dye $)$ of LMT with bromocresol green (BCG) at $\mathrm{pH} 5.02 \pm 0.01$ and extraction of the complex into dichloromethane followed by the measurement of the yellow ion-pair complex at $410 \mathrm{~nm}$. In the second (method B), the drug-dye ion-pair complex was dissolved in ethanolic potassium hydroxide and the resulting base form of the dye was measured at $620 \mathrm{~nm}$. Beer's law was obeyed in the concentration range of 1.5-15 $\mu \mathrm{g} \mathrm{mL}^{-1}$ and $0.5-5.0 \mu \mathrm{g} \mathrm{mL}^{-1}$ for method A and method B, respectively, and the corresponding molar absorptivity values are $1.6932 \times 10^{4}$ and $3.748 \times 10^{4}$ $\mathrm{L} \mathrm{mol}{ }^{-1} \mathrm{~cm}^{-1}$. The Sandell sensitivity values are 0.0151 and $0.0068 \mathrm{\mu g} \mathrm{cm}^{-2}$ for method $\mathrm{A}$ and method $\mathrm{B}$. The Sacly. The stoichiometry of the ion-pair complex formed between the method $B$, respectively and dye (1.1) was determined by Job's continuous variations method and the stability constant of the complex was also calculated. The proposed methods were applied successfully for the determination of drug in commercial tablets.
\end{abstract}

Keywords: lamotrigine; spectrophotometry; ion-pair complex; bromocresol green; pharmaceuticals

\section{Introduction}

\section{Lamotrigine,}

henyl)-1,2,4-triazine-3,5ne], is an antico it has been used successfully to treat epilepsy and bipolar disorder as monotherapy and as an adjunct with other antiepileptics for treatment of partial and generalized toxic-chronic seizures. It is also used to treat neurological lesions and as a tranquilizer $[1,2]$.

Lamotrigine is not official in any pharmacopoeia. The analysis of LMT in biological samples is abundantly described in the literature. Chromatographic techniques have been widely employed since they are powerful separation techniques. The methods based on the high-performance liquid chromatography (HPLC) [3-10] high-performance thin layer chromatography (HPTLC) [11] and gas-chromatography (GC) [12] have been described. There is an extensive literature on the determination of lamotrigine in literature on the determination of lamotrigine in pharmaceuticals include planar chromatography capillary electrophoresis $[16,17]$. The immunoassay techniques $[18,19]$ have been developed for 